40-page pamphlet enlarging on the lessons was sent to all interested telovision viewers. This pamphlet contains a series of simple problems printed on detach. able pages, to be sent back when solved to the Institut Pédagogique National.

This project, the first of its kind in Europe, seems to have achieved considerable success.

The corrospondence received by the Institute Pédagogique National has boaten all records. The first transmissions produced more than 2,000 letters from viewers, and more than 12,000 pamphlets have now been sent out.

Certain industrial firms have organized viewing facilities for their technical personnel, with an instructor present. Twelve copies of each film have already been ordered for various schools. The Univorsity of Montpellier intends to use them on the occasion of the Journéos Nucléaires during March 1962. Translations are already being requested from foroign countries.
J. Debiesse:

\title{
RUDOLPH VIRCHOW MEDICAL SOCIETY
}

T HE ono-hundredth anniversary of the Rudolf Virchow Medical Society of Now York was marked by special celebrations. In his presidential address*, Prof. Joseph Berberich described how the original Society, Deutscher Medizinischer Lcseverein von New York, was foundod in December 1860 by a small group of German physicians, some of whom had left their Fatherland after the Rovolution of 1848. They wanted that freedom of expression for the same reason that led the patron of the Society, Rudolf Virchow, to emigrate at the same time from Berlin to the relatively free and open-minded University of Würzburg in Bavaria.

They lived mostly in the German quarters and met twice a month for the reading of papers and discussion. The rules of the Society were very strict, with Prussian discipline. If someone was absent from a. meoting he was penalized 25 cents. $A$ number of German medical journals were read and exchanged among the members. By 1888 the number of members incroased to 177 , and the name was changed to the German Medical Society in the City of New York The reputation of the Society grew, and many outstanding physicians from Germany and Austria came to lecture to the Society. Men like E. von Leyden, Robert Koch, P. Ehrlich, F. von Exmarch, Friederich von Müller, F. Sauerbruch, H. Strauss, Pasteur, Victor Schmieden, Killian and others read papers more or less as ambassadors of the European, and particularly of German, medicine, whish was then at its highest level.

- Proceedings of the Rudolf Virchoro Medical Society in the City of New York. 19, 1960 . Edited by Hans E. Bejach, Hans Lehfeldt and George Schreiber. Pp. vi +246. (Basle and New York: S. Karger, 1061.) 31 Swiss franes.
A second and influential impulse came after the First World War. The lost war and economic disaster made living difficult for many physicians in Cermany. A great number left Germany for the United States. Those who stayed in New York found rofuge in the Society. At the time it was not difficult for the newcomers to mix with the native physicians, since many American doctors were trained in Germany and Austria and were well versed in the German language.

Medical life after the First World War became more stimulating. With enormous financial backing the United States was soon a leading nation in the field of medicine. The gathering of political clouds in Europe in the beginning of the 'thirties cast a shadow on the Society. Political friction started among members and a number of them resigned. The exodus of a misled group of fanatics did no permanent harm. On June 10, 1939, the namo was changed to the Rudolf Virchow Modical Society in the City of New York.

Almost at the same time (1938-39) came the third and greatest influx of German and Middle-European physicians to the United States. This wave of medical emigrants brought not only their own patients but also a good medical training and considerable exporience. Members of the Society did fundamontal roscarch in nerve electrophysiology, in the development of insulin shock, electro-shock or electroencephalography, the cure of tuberculosis with now ohomicals, treatment of nephrosis, histopathology of mental diseases, introduction of wetting agents into dermatology, the tuberculin patch test, noradrenalin in hyportension, mercury as a diureticum, diagnostic $\mathrm{X}$-ray methods such as arteriography and venography, and myelography.

\section{CENSUS OF SOVIET ZOOLOGISTS}

THE Zoological Institute of the U.S.S.R. Academy of Sciences published, in the form of a small book*, a list of Soviot zoologists, based on replios to a questionnaire sont out in 1958 to all universitics, research institutes and organizations employing pure and applied zoologists. Although the editors complain that many zoologists did not fill in the returns, the list comprises 2,738 (not 2,800 as stated in the preface) entries. It is arranged in alphabetical order of surnames and for each person his full name (both in Russian and in Latin characters), dato of birth, present post, official and privato address, and his speciality aro given.

* Zoologists of the Soviet Dnion. Pp. 290. (Moscow-Leningrad, 1961).
A classification by specialists at the end of the book is of interest, providing some indication of the present trends in Soriety zoology. The largest group (509) is that of parasitologists; this may reflect tho fact that the director of the Zoological Institute, Academician E. N. Pavlovsky, has devoted many years to doveloping this particular branch of zoology. It is closely followed by entomologists, of which thore are 506 ; but, unfortunately, there is no soparate heading for cconomic entomologists, who appear to be a majority, nor for insect ccologists. Othor mainly applied zoologists include hydrobiologists (272); medical zoologists (140); zoologists working on commercial hunting, wildfowling, ctc. (125); agricultural zoologists ( 2 only); bee specialists (13); 